\title{
Accounting Principles and Methods for the Knowledge Assets: Perspectives from the Past Input and Future Output in R\&D
}

\author{
Xi-Rong Gao, Na Yang, Jian Yang, Si-Nian Liu \\ School of Economics and Management, Chongqing University of Posts and Telecommunications \\ Chongqing, China \\ E-mail: xirongg@163.com,772607578@qq.com, 511167113@qq.com, 1144062582@qq.com
}

\begin{abstract}
The accounting principles for the knowledge assets were built up in order to support the operation and management of the knowledge economy; and the accounting measurement methods were discussed from the perspectives of past input and future output in $R \& D$ respectively, taking the patent assets as example. The trait of the soft measurement in the knowledge assets accounting was a great breakthrough to the traditional accounting system oriented within physical assets. The establishment and implementation of the accounting system would provide accounting tools for enterprises to create and manage their knowledge, and supply basic data for countries to investigate and analyze the national knowledge assets as well.
\end{abstract}

\section{Keywords-Knowledge assets; Accounting system; Soft} measurement

\section{INTRODUCTION}

In the past ten years, the world economy has entered a critical period of accelerating transformation from industrial economy to knowledge economy. In the era of knowledge economy, macro factors of production will change from the resource (physical) type elements to knowledge (intelligent) type elements (Yu,2004), and the core of micro management would transform from its physical assets to the knowledge assets (Yuan, 2000). However, as a basic tool for business management, the accounting system is still stuck in the physical asset stage, and this kind of traditional accounting system is difficult to bear the function of knowledge assets accounting. Therefore, at the time of rapid economic transformation, it's urgently need to construct the accounting principles and methods for knowledge assets, to adapt to the management of the knowledge economy.

In order to cope with the economic transformation, the U.S. Department of Commerce adjusted the gross domestic product (GDP) accounting system in July 2013. It capitalizes the technology, knowledge, intelligence, innovation and other soft elements and brings them into the GDP accounting. In fact, the practice in the United States is to recognize the concept of knowledge assets from the macroscopic point of view. Stewart (1991) first put forward the concept of knowledge assets, and the Organization for Economic Cooperation and Development (OECD) in the report, "The Knowledge-Based Economy ", in 1996, classified knowledge into four types: know-what, know-why, know-how and know-who. Baruch Lev (2001) suggested that the growth of wealth and economic of current society was mainly driven by intangible assets, but Barnes \& McClure
(2009) showed that there was a serious problem that the intangible assets expenditure was considered as the current cost rather than investment, and this measurement method affected the evaluation of its value increment. So Corrado, Hulten \& Sichel $(2005,2009)$ created CHS method to count and measure intangible assets directly and David Kirkwood(2001)suggested that the value of knowledge assets (ROK) was the sum of creation cost (CO), holding cost $(\mathrm{CM})$ and the application value (BU) of knowledge assets. About the domestic researches, Xiang \& Yang (2014) suggested that knowledge assets were a kind of unique asset and Yang \& Jiang (2006) divided knowledge assets into four types: experience knowledge assets, conception knowledge assets, system knowledge assets and practice knowledge assets. Xiang (2006) suggested the reform path of progressive knowledge assets accounting should be a relatively safe choice, taking the knowledge assets into accounting system.

The most obvious difference between knowledge assets and traditional physical assets is that knowledge assets have double characteristics both of the experience and of optionality; however, physical assets have neither the characteristic of experience nor the characteristic of optionality. Although the current accounting system partially accounts the patent assets, which belongs to the knowledge assets, its accounting principles refer to physical assets and it does not reflect the experience and options of patent assets. In view of the defects of the traditional accounting system, this paper puts forward the past input of knowledge assets and the future output of knowledge assets from the double visions of experience and optionality, and constructs accounting principles and methods of knowledge assets.

At present, China is in the period that there are outstanding contradictions between the excess of physical assets (showed as the excess capacity) and the shortage of knowledge assets (showed as the original problem). In order to resolve the contradiction, China put forward the strategy of innovation-driven to promote the massive entrepreneurship and innovation and open the journey of the construction of innovative country. Under such circumstances, it is a great strategic significance to build the accounting theory and method of knowledge assets, to support the national innovation transformation from the accounting system. 


\section{II.CONCEPT SYSTEM OF KNOWLEDGE ASSETS}

\section{A. The Definition of Acknowledge Assets}

Knowledge assets are the knowledge, which can produce goods, service and other knowledge. According to the economic value, this paper divides knowledge assets into three types, theoretical knowledge assets, applied knowledge assets and business knowledge assets.

\section{1) Theoretical knowledge assets}

Theoretical knowledge assets are the knowledge assets, which not only produce no direct economic performance, but also have no potential economic value. They include academic thoughts, scientific principles, theoretical models, scientific method, etc. (For example, the Pythagorean Theorem, the Newton's Laws and the Element's Periodic Law). And they mainly exist in science, liberal arts and other basic subjects. To build the accounting measurement, we use the indexes of theoretical scientific and technological achievements, including academic papers, academic works, etc.

\section{2) Applied knowledge assets}

Applied knowledge assets are the knowledge assets, which cannot produce direct economic performance, but have potential economic value. They include applied technologies not aimed at specific goods, general engineering technologies, etc. (For example, the general building technologies, medical technologies, manufacturing technologies, agricultural technologies and management technologies). And they mainly exist in industry, health care, agriculture, construction, business and other applied subjects. To build the accounting measurement, we use the indexes of engineering technical achievements, including engineering paper, technical works, general technical standards, general construction methods, etc.

\section{3) Business knowledge assets}

Business knowledge assets act on the specific business activities, and can produce direct economic performance. They include practical technologies, engineering projects, technological processes, product prototypes, which are aimed at specific goods and business. (For example, the computer production technologies, electronic chip models and automobile assembly lines). Moreover, they mainly exist in product R\&D organizations and production service departments. To build the accounting measurement, we use the indexes of production technology achievements, including patents, non-patented technologies, trademarks, software, knowhow, etc.

\section{B. The Input and Output of Knowledge Assets}

Knowledge assets have double characteristics both of the experience and of optionality. The experience characteristic can be explained that the production process of knowledge assets is essentially a kind of assets. The optionality characteristic can be explained that the knowledge assets value mainly depends on its future value. Given that, the accounting measurement methods were discussed from the perspectives of past input and future output in $R \& D$ respectively.

\section{1) The input of knowledge assets}

During the knowledge production process, the R\&D experience is not replicable wealth, whether successful or not. That is to say, $\mathrm{R} \& \mathrm{D}$ process itself has important asset value, so this paper we call it experience assets or the input of knowledge assets. The essential meaning of the input of knowledge assets is that once you experienced, what you attained becomes assets. Given the positive relationship between the accumulation of experience and $R \& D$, we use $R \& D$ indexes to measure the value of the input of knowledge assets.

\section{2) The output of knowledge assets}

Once knowledge is produced, it has long-term expected time value in the future just like the optionality. The long-term expected value is mainly manifested in continuous support for the production of knowledge and goods in the future, and the supporting roles are the essential of assets. So this paper we call it (the future value) the output of knowledge assets. In general, the duration of the future value of the knowledge assets is far longer than the physical assets, and even can tend to infinity in the future, theoretically. To build the accounting measurement, we use the real option approach, which is based on the current value of knowledge achievements, and get the discounted value during the effective period of knowledge.

Fig. 1 is the concept system of knowledge assets.

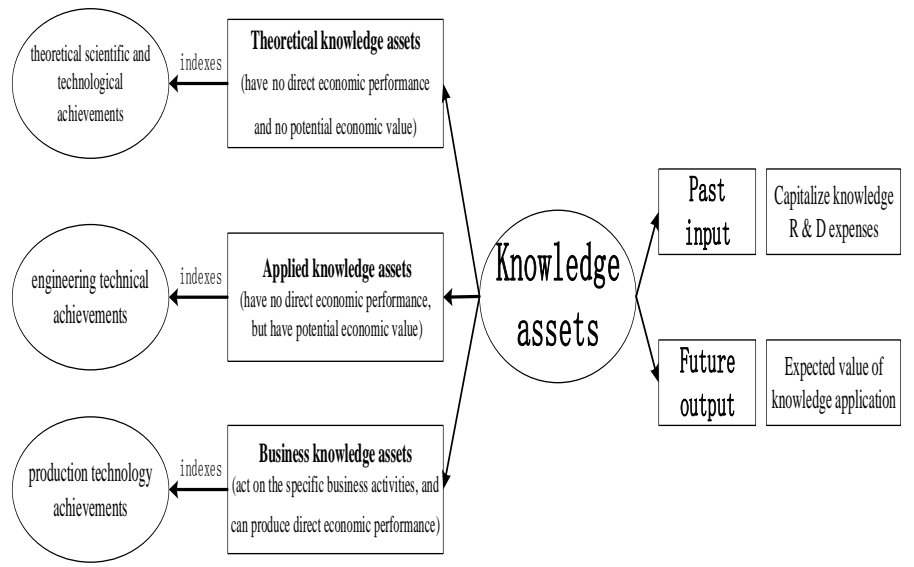

Figure 1 The concept system of knowledge assets

Among the knowledge assets, patent assets are typical. In order to describe the patent assets systematically, we draw the concept system of patent assets by reference to the Figure. 1. (See Fig. 2).

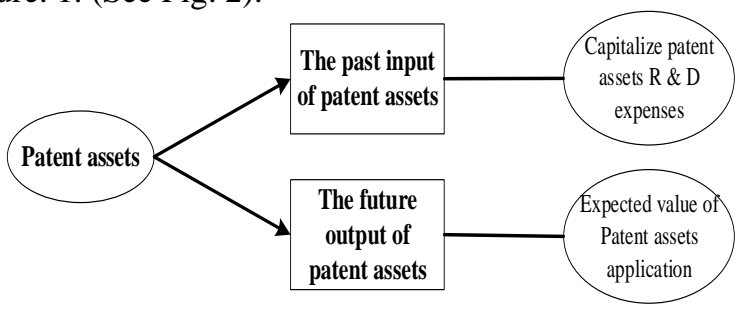

Figure 2 The concept system of patent assets 


\section{ACCOUNTING PRINCIPLES OF KNOWLEDGE ASSETS}

\section{A. Accounting Subjects of Knowledge Assets}

The first level accounting subject "knowledge assets" is set up to collect the total value of the knowledge assets. Under the first level subject, it is divided into three secondary accounting subjects respectively to be as "theoretical knowledge assets", "applied knowledge assets" and "business knowledge assets", for summarizing the value of the three types of knowledge assets. In the second level subjects, the third level accounting subjects are used to record the asset value of a specific $R \& D$ project (See Table 1).

TABLE I. ACCOUNTING SUBJECTS OF KNOWLEDGE ASSETS

\begin{tabular}{|c|c|c|}
\hline $\begin{array}{c}\text { The first level } \\
\text { subject }\end{array}$ & $\begin{array}{c}\text { The second level } \\
\text { subjects }\end{array}$ & The third level subjects \\
\hline \multirow{3}{*}{$\begin{array}{c}\text { Knowledge } \\
\text { assets }\end{array}$} & $\begin{array}{c}\text { Theoretical knowledge } \\
\text { assets }\end{array}$ & $\begin{array}{c}\text { A theoretical achievement } \\
\text { asset }\end{array}$ \\
\cline { 2 - 3 } & $\begin{array}{c}\text { Applied knowledge } \\
\text { assets }\end{array}$ & $\begin{array}{c}\text { An engineering technology } \\
\text { asset }\end{array}$ \\
\cline { 2 - 3 } & $\begin{array}{c}\text { Business knowledge } \\
\text { assets }\end{array}$ & $\begin{array}{c}\text { A production technology } \\
\text { asset }\end{array}$ \\
\hline
\end{tabular}

B. Accounting Principles of the Input of Knowledge Assets

1) Setting accounting subjects of the input of knowledge assets.

Under the third level accounting subjects, the "the input of knowledge assets" subject is used to record the past input of a specific R\&D project (See Table 2).

TABLE II. ACCOUNTING SUBJECTS OF THE INPUT OF KNOWLEDGE ASSETS

\begin{tabular}{|c|c|}
\hline $\begin{array}{c}\text { The third level } \\
\text { subjects }\end{array}$ & The input of knowledge assets \\
\hline $\begin{array}{c}\text { A theoretical } \\
\text { achievement asset }\end{array}$ & The past input of a theoretical achievement asset \\
\hline $\begin{array}{c}\text { An engineering } \\
\text { technology asset }\end{array}$ & The past input of an engineering technology asset \\
\hline $\begin{array}{c}\text { A production } \\
\text { technology asset }\end{array}$ & The past input of a production technology asset \\
\hline
\end{tabular}

2) Accounting procedures of the input of knowledge assets

Two phases of bookkeeping process are used to record the input of knowledge assets of a specific R\&D project.

At first phase, do the bookkeeping of the expense happened during the project research: Debit: R\&D expenditures, Credit: bank, raw materials, wages, asset depreciation and other related subjects."

At second phase, make sure that all the $R \& D$ expenditures are capitalized, regardless of success or failure, after the end of the R\&D project. Namely, all the R\&D past input is transferred from cost accounts to knowledge assets account, that is, Debit: knowledge assets, Credit: R\&D expenditures (See Fig. 3).

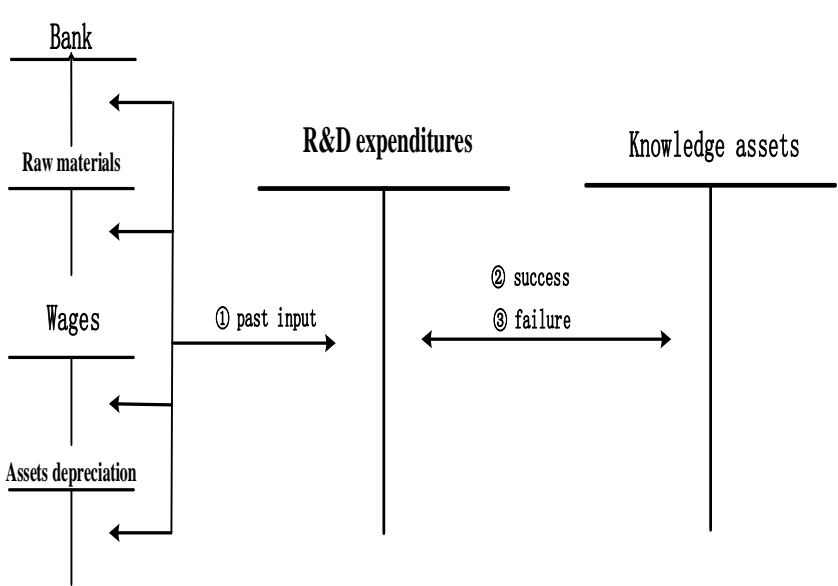

Figure 3 Accounting procedures of input assets

3) Accounting model of the input of knowledge assets

The past input of knowledge assets is measured by the total cost of $R \& D$ expenditures. $R \& D$ expenditures include eight categories:

- Material, fuel and power costs directly consumed by $\mathrm{R}$ \& D activities;

-Wages, bonuses, allowances, social insurance, housing provident fund and other labor costs, as well as external R\&D personnel labor costs;

- Depreciation expense for equipment, equipment, housing and other fixed assets used in R\&D activities;

- Amortization of intangible assets such as software, patents, non-patented technologies used in R \& D activities;

- For the intermediate test and product development of the mold, process equipment development and manufacturing costs, samples, prototypes and the acquisition of general testing means, the inspection fees for the manufacture of products, etc.;

- Research and development achievements appraisal, review and acceptance, assessment and the application fee of the intellectual property rights, the registration fee, the agency fee, etc.;

- The cost of R\&D project commissioned by individuals or other units through outsourcing, cooperation and other ways.

- Other expenses directly related to R\&D activities, including technical books and information fees, expert consulting fees, training fees, conference fees, travel expenses, fixed asset leasing fees and related fixed assets maintenance, etc.

The general accounting model of the input of knowledge assets is also found in the formula (1).

$$
A_{\text {in }}=P+W+D+B
$$

In the formula (1), Ain refers to the input of knowledge assets, $\mathrm{P}$ is the first category R\&D expenditure (cost of consumables), $\mathrm{W}$ is the second category $\mathrm{R} \& \mathrm{D}$ expenditures (labor costs), $\mathrm{D}$ is the third and the fourth category $\mathrm{R} \& \mathrm{D}$ expenditures (depreciation and amortization expenses), B is the fifth, sixth, seventh, eighth category of expenses on R\&D 
(other expenditures).

\section{Accounting Principles of the Output of Knowledge Assets}

1) Setting accounting subjects of the output of knowledge assets

Under the third level accounting subjects, "the output of knowledge assets" subject is established to record the future value of a specific R\&D project (See Table 3).

TABLE 3. ACCOUNTING SUBJECTS OF THE OUTPUT OF KNOWLEDGE ASSETS

\begin{tabular}{|c|c|}
\hline $\begin{array}{c}\text { The third level } \\
\text { subjects }\end{array}$ & The output of knowledge assets \\
\hline $\begin{array}{c}\text { A theoretical } \\
\text { achievement asset }\end{array}$ & The future value of a theoretical achievement asset \\
\hline $\begin{array}{c}\text { An engineering } \\
\text { technology asset }\end{array}$ & The future value of an engineering technology asset \\
\hline $\begin{array}{c}\text { A production } \\
\text { technology asset }\end{array}$ & The future value of a production technology asset \\
\hline \multicolumn{2}{|c|}{ 2) Accounting model of the output of knowledge assets } \\
\hline
\end{tabular}

The value of the output of knowledge assets is the long-term expected value in the future, its measurement rule is based on the future value of the knowledge achievements, and the value is discounted at the effective accounting period. The general accounting model is found in the formula (2).

$$
A_{\text {out }}=\sum_{t=1}^{n} \frac{V_{t}}{(1+i)^{t}}
$$

In formula (2), Aout refers to the output of knowledge assets, $\mathrm{Vt}$ is the future value at the time of $\mathrm{t}, \mathrm{i}$ is the discount rate, $\mathrm{n}$ is the expected time for asset use.

\section{Accounting Summary of Knowledge Assets}

The total amount of the input and output of knowledge assets, as shown in the formula (3), shall be added to the value of the knowledge assets.

$$
K A V=A_{\text {in }}+A_{\text {out }}
$$

In formula (3), KAV refers to the value of knowledge assets.

\section{ACCOUNTING METHODS OF THE PATENT ASSETS}

Patent assets are the main form of business knowledge assets. In view of the convenience of patent assets data acquisition, the following will be based on the accounting principles of knowledge assets, to demonstrate the accounting methods of patent assets.

\section{A. Accounting Methods of the Input of Patent Assets}

\section{1) Accounting procedures of the input of patent assets}

Two phases of bookkeeping process are used to record the input of patent assets.

At first phase, conduct the bookkeeping of the expense happened during the $R \& D$ project research, that is, Debit: R\&D expenditures-business knowledge assets-XX patent asset, Credit: raw materials, bank, wags, asset depreciation, etc.
At second phase, all the R\&D expenditures should be capitalized after the end of the $R \& D$ project, namely, transferring the $R \& D$ expenditures from cost accounts to knowledge assets account: Debit: knowledge assets-business knowledge assets-XX patent asset, Credit: R\&D expenditures-business knowledge assets-XX patent asset.

2) Accounting formula of the input of patent assets

The accounting formula of the input of patent assets, is shown as follows (See formula (4)), referred to the formula (1).

$$
A_{\text {in }, p}=P+W+D
$$

In formula (4), Ain,p refers to the input of patent assets.

\section{B. Accounting Methods of the Output of Patent Assets}

The output of patent assets is long-term expected value of the patent application in the future. The accounting procedures are as follows.

1) Calculating the net profit rate of technology transactions

At first, collect the amount of technology market transactions, which acts as the technical output index, and the total $R \& D$ expenditures, which act as the technical input index. Secondly, calculate the average technical input and output rate $\mathrm{Np}$ (See formula (5)).

$$
\mathrm{N}_{\mathrm{p}}=\frac{\text { the amount of technology market transactions }}{\text { the total R\&D expenditures }}
$$

Finally, calculate the average net profit rate of technical transactions Rp based on Np by formula (6).

$$
R_{p}=N_{p}-1
$$

\section{2) Accounting formula of the output of patent assets}

Based on the input of patent assets data, as well as the average net profit rate of technology transactions, the future annual value of patent assets is calculated. (See formula (7)).

$$
A_{p}=A_{\text {in,p }} \times R_{p}
$$

According to the expected duration of use of patent assets (the protection period of the invention patent is 20 years, the protection period of the utility model and the design is 10 years), discount the annual value of patent assets in the future use period. When determining the discount rate, the interest rate can be considered as a risk free interest rate, and the 5-year Treasury bond interest rate will be considered as the discount rate. Therefore, the accounting formula of the output of patent assets is shown as follow. (See formula (8)).

$$
A_{\text {out }, p}=A_{p} \sum_{t=1}^{n} \frac{1}{(1+i)^{t}}=A_{p} \times P V I F A_{i, n}
$$

In formula (8), Aout,p refers to the output of patent assets, 
$\mathrm{i}$ is the 5 year bond interest rate (the discount rate), $\mathrm{n}$ is the patent protection period, PVIFAi, $\mathrm{n}$ is the present value coefficient of annuity.

\section{3) Accounting procedures of patent output assets}

According to the current accounting standards, the output of patent assets can be included in the account of capital subject. The accounting is shown as follows: Debit: knowledge assets-business knowledge assets-XX patent asset, Credit: capital.

\section{Accounting Summary of Patent Assets}

The formula for summarizing the value of patent assets is shown below. (See formula (9)).

$$
K A V_{p}=A_{\text {in,p }}+A_{\text {out }, p}
$$

In formula (9), KAVp refers to the value of the patent assets.

\section{V.CONCLUSIONS}

In order to cope with the transformation from industrial economy to knowledge economy and meet the practical needs of the management of knowledge economy, this paper builds the concept system of knowledge assets, and puts forward the input of knowledge assets and the output of knowledge assets and their measurement methods in view of double characteristics both of the experience and optionality. Based on that, this paper constructs the accounting principles and methods of knowledge assets. The main research results are as follows:

- Knowledge assets are the knowledge that can produce other knowledge. There are three types including theoretical knowledge assets, applied knowledge assets, and business knowledge assets.

- Given in the process of knowledge production, the R\&D process itself has important asset value, whether successful or not. According to that, this paper puts forward the input of knowledge assets and their measurement methods, to calculate the process value of knowledge production.

- In view of the long term value of knowledge production, this paper puts forward the output of knowledge assets and their measurement methods, to calculate the knowledge option value in the future.

- Establishing and implementing the accounting principles and methods of knowledge assets, not only provide accounting tools for enterprises to create and manage their knowledge at micro level, but also supply basic data for the country to investigate and analyze national knowledge assets at macro level.

The accounting principles and methods of knowledge assets constructed in this paper make the accounting system promote from the traditional physical measurement categories to the soft measurement categories of knowledge economy. This transformation breaks through the traditional framework of industrial accounting system, and it will greatly activate the creativity and vitality of the whole society. It is great significant to promote the massive entrepreneurship and innovation and construct an innovative country.

\section{REFERENCES}

[1] Baruch Lev, Intangibles, Management, Measurement, and Reporting, CA: The Brookings Institution Press, 2001, pp. 1-8.

[2] Corrado, C., C. Hulten, D. Sichel, "Measuring capital and technology: An expanded framework", The National Bureau of Economic Research, Tech. Rep., 2005.

[3] Corrado C., C. Hulten, D. Sichel, "Intangible capital and U.S. economic growth", Review of Income and Wealth, vol.55, no.3, pp. 661-685, 2009.

[4] Kirkwood D., "Creating a return from knowledge assets", Knowledge Management, vol.5, no.1, pp. 43-47, 2001.

[5] OECD, "The Knowledge-Based Economy", the Organization for Economic Co-operation and Development, Tech. Rep., 1996.

[6] Stewart, T. A., "Brainpower: How Intellectual Capital is Becoming America's Most Valuable Asset”, Fortune, vol.62, no.6, pp.40-56, 1991.

[7] Jiang, C. \& S. Yang, "Research on the Formation Mechanism of Knowledge Innovation and Enterprise Knowledge Assets". Forum on Science and Technology in China, vol.22, no.5, pp. 82-86, 2006.

[8] Xiang, X. \& X. Guo, "Knowledge Assets, Value Management and EVA Improvement", Research of Finance and Accounting, vol.35, no.6, pp.56-59, 2014.

[9] Xiang, Z, "Obstacle and Choice of Intellectual Assets Accountant", Communication of Finance and Accounting, vol.27, no.3, pp. 97-99, 2006.

[10] Yu, X, "New Characteristics of Management Accounting under the Condition of Knowledge Economy", Economic Issues in China, vol.46, no.2, pp. 52-59, 2004.

[11] Yuan, Y, "Discuss the New Characteristics of Business Management in the era of Knowledge Economy", Jiangxi Social Sciences, vol.21, no.10, pp. 22-24, 2000.

[12] Zhang Y, "Research on the Economic Effect of R\&D Investment in Manufacturing Industry", Scientific Management Research, vol.26, no.5, pp.175, 2006. 